\title{
Myang ral Nyi ma 'od zer (1124-1192): Authority and Authorship in the Coalescing of the rNying ma Tantric Tradition
}

\section{Cathy Cantwell*}

The eleventh to thirteenth centuries in Tibet witnessed the development of religious schools based on the "New Transmissions" (gsar 'gyur) of Buddhist Tantras or the "Later Spread" (phyi dar) of Buddhism, in contrast to the "Early Transmissions" (snga 'gyur) of Tibetan Imperial times (seventh to ninth centuries $\mathrm{CE}$ ). This period saw the beginnings of the system in which Buddhist monasteries became seats of religious and politico-economic authority throughout communities in Tibet. At the same time, in this culturally creative environment, followers of the "Ancient Transmissions « began to codify their textual heritage, resulting in the subsequent development of a rNying ma school, based especially on:

i. the practice of the Inner Tantras (mahāyoga, anuyoga, atiyoga) and the Eight Sacred Word (bka' brgyad) tantric deity cycles;

ii. the related textual corpus of scriptures known as the "Ancient Tantra Collection« (rnying ma rgyud 'bum);

iii. popular accounts of and rituals connected with the early tantric masters and their spiritual and magical feats, and especially the cult of the tantric guru and »second Buddha«, Padmasambhava, together with his key disciples;

iv. the traditions of revelation, in which revealers identified as rebirths of the tradition's cultural heroes continue to augment the textual heritage in each generation.

Myang ral Nyi ma 'od zer was seminal to this development: himself a tantric revealer recognised as a rebirth of the emperor Khri srong lde'u btsan, he was responsible for a multi-volume revealed collection on the Eight Sacred Word deities, the Eightfold Sacred Word, Embodying the Sugatas (bka' brgyad bde gshegs 'dus pa); was central to the lineage of the transmitted texts ( $b k a^{\prime} \mathrm{ma}$ ) on the same deities; and produced the first full hagiography of Padmasambhava, while his immediate successors began the work of collecting the scriptures for the »Ancient Tantra Collection«, based on organising principles established in his work. This article probes how we should approach authority and authorship in this case. How far and in what sense should we consider Myang ral an "author " of the texts he revealed and why were the new claims to authority so compelling in this case? While Myang ral's involvement with vision and ritual rather than logical argument or debate clearly distinguish him from mediaeval Tibetan scholastics - even those within his own tradition of Early Transmissions yet his impressive work in compiling and systematising the heritage from his mentors would suggest that the contrast may not be as extreme as it would first appear.

Keywords: Tantric revelation; early rNying ma; Myang ral

* Correspondence details: Dr. Cathy Cantwell, Wentways, Hackington Place, Canterbury, Kent CT2.7JR, U.K.; email: Catherine.Cantwell@ruhr-uni-bochum.de. 
Modern academic Tibetan Studies has drawn attention to a discrepancy between traditional Tibetan presentations of the introduction of Buddhism into Tibet, and what we know from the archaeological record and the earliest Tibetan documents. ${ }^{1}$ The historical evidence points to Buddhism introduced by state sponsorship, primarily in the eighth century during the reign of the Tibetan emperor Khri srong lde'u btsan, with an emphasis on standard Mahāyāna Buddhist doctrine and ethics, and on what would later be classified as outer tantra, especially the cult of Vairocana. The teachings which were later classified as the inner tantras, involving a more direct path and potentially antinomian practices, seem to have been restricted, and the texts at least not officially translated. At the same time, notwithstanding the rivalries between the missionary religion and indigenous ritual specialists, non-Buddhist Tibetan religious traditions coexisted with Buddhism at court, and remained important in state ritual and popular religion. It was only in the period after the empire's collapse in the mid-ninth century, when the institutionalised Buddhism of the state-sponsored temples declined, that Buddhism seems gradually to have permeated the society, while tantric rites of all kinds, no longer subject to state restriction, seem to have gained in popularity. From the late tenth to eleventh centuries, a so-called Later Spread (phyi dar) of Buddhism introduced further Buddhist traditions from India, sponsored by regional rulers and aristocratic families.

In contrast to this picture, historical/mythological accounts from Myang ral Nyi ma 'od zer's era, such as the Ma ni bka' 'bum collection (see note 4 below), stressed the centrality of the inner tantric traditions from the outset. Myang ral himself compiled a narrative about the Early Spread (snga dar) of Buddhism, highlighting the dominance of the tantric master Padmasambhava or the Precious Guru ( $g u$ ru rin po che), seen as a second Buddha, teaching a circle of students headed by the king, his family and his noble subjects. Many traditional historical accounts, penned by Buddhist scholars through the ages, followed suit. Moreover, the developing rNying ma religious tradition became Padma-centric in almost all respects, with increasingly mythological components of narrative and religious imagery integrated into ritual performances. Given the gulf between such presentations and the surviving historical evidence, it is hardly surprising that modern academic scholars have often tended rather to treat traditional accounts of the tantric transmissions preceding Myang ral as essentially mythological, or at least as unproven stories. In a recent research project on Myang ral at the University of Bochum (2017-2019) which considered how his works fit with what went before and with what followed, we have gained some sense of the ways in which Myang ral was indebted to the generations before him, ${ }^{2}$ and we can begin to picture a few aspects of the traditional narrative which may have had an historical basis.

1 Kapstein, Tibetan Assimilation of Buddhism, gives a thorough analysis of the gradual development and transformation of the various religious strands in early Tibet, and the new constructions of religious identity which took place over the first few hundred years of Buddhism's presence in Tibet. The contrast between the Buddhism of the Imperial period and the accounts witnessed in the later religious histories is so stark that Kapstein, Tibetans, 6869 , comments, »the religious view of the past cannot be readily reconciled with the demands of critical history«. Snellgrove and Richardson, Cultural History of Tibet, chapters 2-3, also trace the extraordinary cultural development which took place over the early generations of Buddhism in Tibet.

2 The main output of my own work on the Bochum project, Cantwell, Action Phurpa, is a primarily philological analysis of the Action Phurpa ('phrin las phur pa) section of the Eightfold Sacred Word, Embodying the Sugatas (bka' brgyad bde gshegs 'dus pa). 
Scholarly tantric masters representing the "Early Transmissions" (snga 'gyur) of Buddhism predating Myang ral include the ninth- to tenth-century figure of gNubs chen Sangs rgyas ye shes, who wrote a learned treatise on the different paths, privileging the Inner Tantras, ${ }^{3}$ and the eleventh-century scholar Rong zom Chos kyi bzang po, who defended the "Early Transmissions" against criticisms made by polemicists of the "New Transmissions" ( $g$ sar 'gyur). At least some of their works survive, but unfortunately, most of the written productions of those considered the tradition's earliest "Treasure Revealers" (gter ston) are no longer extant in their original forms. In some cases, their revelations have been incorporated into later works, so that we cannot identify the exact passages deriving from them. ${ }^{4}$ As a result, Myang ral tends to be treated as though he was the first significant rNying ma Treasure Revealer, and indeed, he produced the earliest corpus of rNying ma revelations. Yet it is quite clear that Myang ral was contributing to an already active culture of visionary revelation.

Myang ral Nyi ma 'od zer lived in lHo brag in southern central Tibet, just north of present-day Bhutan, at a time when Buddhist tantric teachings newly imported from India were causing a stir and gaining wealthy patronage. In representing the older Buddhist tantric teachings already established in Tibet in the Imperial and post-Imperial periods, Myang ral effectively brought together key strands of this earlier heritage of tantric doctrine, mythology, ritual and meditation practice, helping to create a basis for the emergence of a coherent system of practices to represent the Ancient Tantra transmissions. The organisational model was quite unlike that of the newer schools, which soon formed separate lineage groups, each of which were - and sought to remain - socially integrated, often retaining hierarchical relationships between constituent monasteries as the group expanded. Myang ral and his successors seem to have made no attempt to band together to create a single social entity or monastic order. The resultant religious system instead created a shared sense of identity amongst those who followed these teachings. In fact, the rNying ma school did not develop large monastic establishments until the seventeenth century. rNying ma lineages had their monasteries and temples, but in many times and places rNying ma organisation was typified by hereditary tantric lineages and small groups gathering around a master and his family. This system had its own esoteric transmissions claiming to be the "highest " teachings. Yet many aspects of the rites and mythological constructions were not exclusive to the specific tradition, but based themselves around an inclusive mythological narrative of a shared Tibetan heritage of Buddhist transmissions during the glorious days of the Tibetan empire, and the sacralisation of the Tibetan landscape as a sacred land for Dharma practice by this early generation of Buddhist masters. It was Myang ral who apparently revealed the Zangs gling $m a$ (»the Copper Island«), which is the first full-length hagiography of Padmasambhava or Guru Rinpoche, the Precious Guru. Padmasambhava was an Indian tantric master said to have helped in establishing the Buddhist tradition in Tibet during Imperial times through

4 Thus, Myang ral's teacher, Grub thob dNgos grub (see below 73-74) revealed the earliest kernel of the Ma ni bka' 'bum collection (see Kapstein, Tibetan Assimilation of Buddhism, 145-146), while the medical classic, the rGyud bzhi, compiled by g.Yu thog yon tan mgon po, was supposed to have been based on an eleventh-century revelation by Grwa pa mngon shes. The tenth- or eleventh-century lDang ma lhun rgyal is said to have revealed the Great Perfection tantras of the Bi ma snying thig. 
his transmission of inner tantric Mahāyoga traditions, especially those connected with the tantric deity, Vajrakilaya, and his subjugation and conversion of indigenous Tibetan gods, spirits and demons. Amongst his band of followers, it is perfectly possible that he was seen as enlightened, but it is probable that his circle of devotees would have been small, and certainly, the historical record for his activities is minimal. As mentioned above, Myang ral's account linked the Precious Guru with the emperor and the court, and some of the aristocratic families who maintained rNying ma hereditary spiritual lineages through the ages claimed descent from one or the other of a group who were now said to be the close disciples of Padmasambhava. ${ }^{5}$ Myang ral identified himself as a rebirth of King Khri srong lde'u btsan, and presented Padmasambhava as the Second Buddha, uniquely connected to the Tibetan people and Tibetan lands.

There is no doubt that Myang ral was drawing on older materials: I identified one of his verses of praise to the Precious Guru in the Zangs gling ma at the end of the Dunhuang manuscript commentary on the Noble Noose of Methods tantra (IOL Tib J 321). ${ }^{6}$ In bringing together disparate sources into a single hagiography, Myang ral developed the narrative underpinning his tantric spiritual revelations, even if what became the classic normative account of Treasure revelations was not fully or consistently outlined in Myang ral's works. ${ }^{7}$ His hagiography draws attention to a series of transmissions of eight wrathful tantric deities or herukas, each associated with a Tibetan vidyädhara or tantric master, who received transmission from Padmasambhava and demonstrated miraculous signs of accomplishment (the story is told in the Zangs gling $m a$, chapter 19$).{ }^{8}$ Amongst his numerous revelations is his magnum opus known as the bKa' brgyad bDe gshegs 'dus pa (Eightfold Sacred Word, Embodying the Sugatas). This consists of a large corpus of tantric practices relating to this eightfold system, amounting to thirteen volumes in the longest extant versions, although the original may have been less than half this size. ${ }^{9}$ For each section, there is a revealed root tantra, as well as a great deal of further material. This collection became seminal for the later rNying ma pa. The eightfold structure remains significant in later centuries and subsequent lamas had their own Eightfold Sacred Word revelations, including Myang ral's thirteenth-century successor, Gu ru Chos dbang. ${ }^{10}$

5 See Mayer, »We swear«.

6 Cantwell and Mayer, Noble Noose of Methods, 92-94.

7 Hirshberg, Remembering the Lotus Born, 93.

8 Kong sprul's version of the Zangs gling ma gives additional details (see Yeshe Tsogyal, Lotus-Born, transl. Kunsang, 124-127), but even the versions which Doney identifies as the oldest specify the textual heritage associated with each of the eight deities, along with Padmasambhava's bestowal of empowerment on the eight named students, and their subsequent accomplishments (see the text reproduced in Doney, Zangs gling ma, 283-285, MS ZLi, 59r-60v).

9 Myang ral's biographies, most probably penned by the first generation of students following him, speak of the revelation as consisting of either six or seven small volumes (Hirshberg, Remembering the Lotus Born, 100, 129; bKa' brgyad bde gshegs 'dus pa, Gangtok $1 \mathrm{Ka}, 91$; mTshams brag 2 Kha, 341-342).

10 Nicholas Trautz's recent work (Curating a Treasure) draws attention to the role of the Eightfold Sacred Word literature in later times in creating an overarching organisational structure and exegetical template for those inheriting and representing the Early Transmissions. 
The case study here might perhaps be considered unusual as an example of scholasticism - since we are dealing with a tantric visionary who produced a large quantity of revelatory texts concerning esoteric tantric instructions and ritual practices, dealing more with inspiration and guidance than with rational argument or explicit systematic classifications. Moreover, although Myang ral's Eightfold Sacred Word collection would later be enlarged and transmitted through the generations at large monastic establishments, his own religious community centred around himself and his family line. In any case, Myang ral's period predated the development of the monastic scholastic colleges in which Tibetan scholastic training and debate developed and flourished. Yet it may be that the production of this kind of tantric literature has a good deal in common with other forms of classical Tibetan literature which would seem more obviously scholastic in nature.

To appreciate Myang ral's contribution, we must first consider the genres of tantric literature which evolved in the rNying ma tradition:

i. Root tantras, anonymously authored scriptures, considered to have been spoken by a buddha and revealed in the earliest transmissions of the Buddhist tantric tradition in India or sacred sites such as Uḍdiyāna. These tantras began to be compiled into the "Ancient Tantra Collection" (rnying ma rgyud 'bum) in the generations following Myang ral, and they form a supplementary or alternative canon to what became the mainstream scriptural canon used throughout Tibetan Buddhism. ${ }^{11}$

ii. Transmitted materials ( $b k a^{\prime} m a$ ) related to these tantras and to early tantric teachings given in Tibet, including manuals for practice and scholarly commentaries on them. Many (but not all) of these texts have named authors. While some are distinctive, the transmitted texts include many compilations and edited versions of earlier texts.

iii. Pure Vision teachings (dag snang) produced by tantric masters on the basis of visionary encounters with tantric deities - such teachings might be expanded on by later scholars, and enter the transmitted corpus.

iv. Treasure revelation (gter $m a$ ), not unlike Pure Vision, but the revealers are considered to have the special status of Treasure revealers (gter ston). Each Treasure revealer came to be seen as a rebirth of one of the great cultural heroes of the earliest generation of tantric students who had received the teaching from Padmasambhava or another of the earliest masters, and who had made an aspiration to recover the teaching in a future prophesied life. There had been Treasure revealers before Myang ral, and the system seems to have started from the tenth to eleventh centuries in the rNying ma and Bon traditions, but Myang ral's revelations represent the most substantial early corpus of rNying ma revelations by a named individual, and his was a seminal collection in the formation of rNying ma spiritual practice.

11 This is a simplification of complex canonisation processes, in which there may be considered to be multiple »canons" or versions of the scriptures of Buddha Word (bka' 'gyur) and of the associated teachings (bstan 'gyur). The "Ancient Tantra Collection" is distinct, generally shorter and separate from these collections. It is supplementary in that it includes only what are considered to be inner tantras, largely those excluded from the larger collections, and rNying ma monastic centres would often seek to include those larger collections containing scriptures of the common Buddhist and Mahāyāna heritage in their monastic holdings. It is alternative in the sense that its tantras are considered to represent the highest and innermost teachings distinctive of the rNying ma tradition. 
The different classes are generally considered separate and distinct. However, even in the modern period, there are overlaps, with some revelations classed as both Pure Vision and Treasure revelation, and with the incorporation of root tantra materials and bka' ma transmitted teachings into compilations of the revelatory texts. And new revelations may largely repeat earlier revelations and transmitted sources. ${ }^{12}$

When we consider the early period before the systematisation of the rNying ma tradition, there is no doubt that the categories were already in existence, but the boundaries were even more permeable. Janet Gyatso draws attention to the dual classification of a key group of early $r d z o g$ s chen/atiyoga tantras as both Treasure revelations and root tantras. ${ }^{13}$ And Myang ral includes a number of root tantras within his Eightfold Sacred Word collection. These were later included within the "Ancient Tantra Collection", while they were also transmitted with the Eightfold Sacred Word revelatory texts. Myang ral's root tantras seem to reiterate the kinds of materials found in other "Ancient Tantra Collection « tantras of Mahāyoga. They seem to differ only in being presented as Treasure revelation and in the claim at the end of most of them to have represented manuscripts belonging to the emperor Khri srong lde'u btsan (in other words, Myang ral in a previous lifetime). Our research project's case study of Myang ral's root tantra on the tantric deity Vajrakilaya would suggest that this text resembles other rNying ma root tantras in incorporating in several chapters apparently rather obscure and disordered passages, presumably deriving from archaic tantric sources. ${ }^{14}$ But the far greater part of the Eightfold Sacred Word collection is made up of ritual manuals and instructional texts rather than less accessible root scriptures.

In posing the question of what exactly Myang ral's textual productions consist of, and in what sense we may understand his "authorship« of them, striking instances of the re-presentation and reworking of older materials became evident in the course of our research project. Here, I look at two.

1) The division of Myang ral's Eightfold Sacred Word collection specifically devoted to the tantric deity Vajrakilaya comprises a text on the Action Phurpa ('phrin las phur pa) in six parts (bKa' brgyad bde gshegs 'dus pa, mTshams brag 9, 343-503), ${ }^{15}$ which, as a whole, is presented as representing the work of the late Imperial period Indian master Vimalamitra. Whatever its ultimate provenance, my textual study would suggest that the six sections depend upon each other and surely make up a coherent whole. One of these sections

12 Cantwell, Dudjom Rinpoche's Vajrakilaya Works, is a detailed study of ways in which Treasure revelations may develop over time, with passages of text reappearing in the works of later connected revealers, and edited compilations of one revelation including materials from other revelatory and transmitted sources.

13 Gyatso, Apparitions of the Self, 301 n. 69.

14 I am grateful to Dylan Esler's philological analysis of this root tantra in our University of Bochum DFG project (2017-2018); see Esler, Phurpa Root Tantra. Some of the apparent obscurity may be the result of transmissional errors in the versions now available, but it is quite possible that the original text imported ambiguous or disordered recycled passages. Cantwell and Mayer, Kïlaya Nirvāna Tantra, 37-44, 81-82, discuss such issues within other "Ancient Tantra Collection" scriptures, including an example of an entire chapter of text paralleling lines within another tantra, yet with those lines occurring in a quite different order. Another root tantra from Myang ral's corpus has been studied by Grizman, Resurrecting an old advice; and in his forthcoming Ph.D thesis.

15 Note that two further manuscript collections of unknown provenance have recently become available, one in 8 vols. [TBRC W2PD17479], in which the Action Phurpa section is in vol. 6, pdf 659-828, and one in 9 vols. [TBRC W2PD20239], in which the Action Phurpa section is in vol. 6, pdf 693-865. 
(bKa' brgyad bde gshegs 'dus pa, mTshams brag 9, 351-365), despite having a different title, is virtually identical to an anonymous late tenth-century tantric manual of forty pages, which was archaeologically recovered complete and intact at Dunhuang in the twentieth century (IOL Tib J 331.III). ${ }^{16}$ Although the Dunhuang text has only the one section, representing a kind of root text of tantric meditations which the other sections introduce and elaborate on, it now seems clear that Myang ral was reproducing the entire text in six sections, perhaps with some editing - although there would seem little attempt to interfere with the section of text also found in the Dunhuang manuscript.

2) Myang ral is at the fount of both the revelatory and the transmitted bka' ma traditions of the Eightfold Sacred Word deities. The rNying ma pa preserve an account that after receiving his initial revelation, Myang ral was visited by a master of the transmitted literature (Grub thob dNgos grub), who gave him related transmissions and teachings on a cycle known as The Fortress and Precipice (rdzong 'phrang), and that after receiving this, Myang ral merged the transmitted ( $b k a^{\prime} \mathrm{ma}$ ) and revelatory ( ter $\mathrm{ma}$ ) teachings into a single stream. ${ }^{17}$ The earliest Fortress and Precipice texts within the bka' ma collections are said to derive from a manuscript by Myang ral (bKa' ma shin tu rgyas pa Ha 29, 425). Consisting of a series of loosely related tantric instructions connected with the eight deities, our examination of these texts (bKa' ma shin tu rgyas pa Ha 29, 15-425) would suggest that at least some of them were indeed passed on through known tantric masters of the ninth to tenth centuries, and almost certainly did stem from transmissions during Imperial times. In particular, gNubs chen Sangs rgyas ye shes (see above) ${ }^{18}$ and his student are specified under their secret tantric names as transmitting several of these instructions. These texts additionally present themselves in a similar manner to the texts classified as revelations: the final words of a number of them make use of special terms associated with Treasure revelation, and some suggest that gNubs' student buried or hid the teachings as Treasure. In any case, it is clear that Grub thob dNgos grub and Myang ral were key figures in passing on these earlier instructions, which seem to have formed an important basis for the later Fortress and Precipice texts. There may possibly be some overlap between some of the content and that found within Myang ral's Eightfold Sacred Word collection, although this needs further investigation (one possible link is that between the teachings on the four phurpas found in the Fortress and Precipice Ha 29, 230-234, and that in the Eightfold Sacred Word, bKa' brgyad bde gshegs 'dus pa, mTshams brag 4, 527-542, although in that case, there are no close parallel passages). Currently, we can only say that the bka' $m a$ and gter ma texts both came through Myang ral and they have complemented each other in the ongoing transmission. 
Myang ral was a visionary revealer who had a large impact on the later rNying ma tradition, but we need not assume that his works were particularly innovative or new. Even with later revelations, for which the textual productions are considered to be recovered from the revealer's mind, or to be decoded and expanded from a few terse symbolic letters on the basis of the revealer's special karma, memory and realisation of the meaning, much material may parallel earlier sources. In Myang ral's time, before the rNying ma system of Treasure revelations had been fully developed, it seems likely that some Treasure revelations literally consisted of old re-discovered manuscripts, which may have been hidden away following the collapse of institutionalised support for Buddhism in the Imperial period. ${ }^{19}$ And for Myang ral, not only were his revelations materially embodied in textual manuscripts, but he received and authenticated his revelation of the Eightfold Sacred Word in dependence on two other revealers who were his mentors. In one account, he met Ra shag gTer ston and, once four small sacks had been brought forth, Ra shag bestowed the texts upon him, after which the previously mentioned Grub thob dNgos grub gave him the appropriate empowerments. ${ }^{20}$ In the other account, Myang ral is presented as discovering the texts by himself within a statue in an Imperial period sacred temple, but he later met Grub thob dNgos grub, who bestowed the transmissions, and gave him further texts to add to his revelations. ${ }^{21}$ Hirshberg concludes: "Nyangrel's ${ }^{22}$ biographies tone down any sense of innovation in the time leading up to his first recoveries.... he is presented as the karmically destined recipient of established traditions: neither the texts he finds nor the methods he employs are original. Rather than come forward independently with wholly new cycles, Nyangrel's first treasures are those that had already been recovered by other contemporaries and delivered into his hands. ${ }^{23}$ Alongside visionary encounters and tantric realisations, Myang ral, then, may have been concerned as much with gathering together, editing and systematising textual materials inherited and recovered from previous generations - in much the same way as scholarly monastics compiling doctrinal treatises for the early "New Transmission " (gsar ma) schools.

What, then, was the basis of Myang ral's authority, and indeed, of the ultimate success of his Treasure collection for rNying ma spirituality? For Myang ral to be accepted as such an important religious figure, his personal positioning within the emerging rNying ma, the status and transmissions he received through his father as a hereditary lama of an aristocratic religious lineage, and the connections he established with other important tantric masters

19 Hirshberg (Remembering the Lotus Born, 90-92) describes an account suggesting such concealment of Treasures within Myang ral's historical account of the Dharma in Tibet (the me tog snying po).

20 bla ma ra shag gter ston gyi spyan sngar dam chos bde gshegs pa rgyud lung nyi shu sgrub thabs phra mo dang bcas pa/ sgro chung bzhi thon pa la/ pod chung bdun zhus pas dpe ma dang bcas pa gnang/de nas bla ma grub thob dngos grub bya ba bka' gter thams cad kyi bdag po de la/gsang sngags sgrub pa bka' brgyad kyi dbang bka' gdams ngag dang bcas pa zhus/... bum pa gang byo'i tshul du gnang/gter gyi kha byang mang po yang gtad/, Gangtok edition of the bKa'brgyad bde gshegs 'dus pa'i chos skor $1 \mathrm{Ka}, 92-29$; first section translated in Hirshberg, Remembering the Lotus Born, 100.

21 See bKa' brgyad bde gshegs 'dus pa, mTshams brag 2 Kha, 341-342, and 349-350; translated in Hirshberg, Remembering the Lotus Born, 129, 104.

22 Hirshberg uses a phonetical system of transcription in which Myang ral is rendered as Nyangrel.

23 Hirshberg, Remembering the Lotus Born, 104-105.

medieval worlds $\bullet$ No. $12 \cdot 2020 \cdot 68-79$ 
and revealers of the time, were prerequisites to his successful career. ${ }^{24}$ No doubt his selfrecognition as the rebirth of the emperor Khri srong lde'u btsan helped to boost his authority and the claim to authenticity of his works. And as in contemporaneous Kashmir Śaivism, revelation of tantric scripture served to enhance a guru's reputation. ${ }^{25}$ Yet none of these personal qualities would in themselves have been sufficient to establish Myang ral's revelations as the important template of rNying ma spirituality which they became. Perhaps in the context of a forum considering the role of medieval scholasticism, it is worth highlighting Myang ral's comprehensive codification of this system of tantric ritual practices, underpinned by a related mythological origin narrative, linking the spiritual to the Tibetan landscape and the glories of the Imperial past. The impressive integration and consolidation of disparate elements of the religious heritage surely had something to do with the lasting success of Myang ral's project.

rNying ma tantric revealers such as Myang ral might be seen as the "other " of Tibetan scholasticism, privileging reliance on tantric masters and yogic vision over rational argumentation and the systematic structuring of doctrine. The rNying ma tradition did produce some scholars who might fit closely into the scholastic model proposed by Cabezón (this volume) - indeed, the above-mentioned eleventh-century Rong zom Chos kyi bzang po might be considered a good example for the early period. Thus, Rong zom became known for his use of reasoning to establish the rNying ma tantric view, ${ }^{26}$ and took part in polemical debate with those who questioned the authenticity of the tantras of the Early Transmissions. ${ }^{27}$ Even before this time, in which the followers of the Early Transmissions needed to develop a defence for their positions, gNubs chen Sangs rgyas ye shes (see above p. 69) had been active in systematising the rNying ma tantric path, and producing an impressive scholarly heritage. In a later period, when monastic colleges were becoming centres for scholastic training and exchange, Klong chen rab 'byams pa (1308-1364) spent time at the famous college of gSang $\mathrm{phu}$, and became a virtuoso scholar who engaged in extensive learned expositions of the spiritual path, drawing on elements deriving from different Buddhist traditions but ultimately supporting the supremacy of the rNying ma Inner Tantras. There is no doubt that a view of the rNying ma as anti-scholastic or as exclusively orientated to meditation practice is misleading. ${ }^{28}$ These rNying ma scholastic figures nonetheless combined their scholarly careers with deep involvement in the tantric practice lineages. As noted above (p. 73), Myang ral is associated with transmitting a series of tantric teachings apparently deriving from gNubs chen. Yet Myang ral himself was not at the forefront of rNying ma scholastic exegesis: he is famed rather for his mastery of visionary materials. However, the strong emphasis on preserving tradition, with concern for reproducing the communal legacy passed on from his mentors, along with the systematic ordering of diverse inherited tantric materials into an overarching schema for religious practice, might suggest that the opposition should not be overstated in this Tibetan case.

Doney, Zangs gling ma, 9-22; Hirshberg, Remembering the Lotus Born, chapters 1-3.

25 Robert Mayer's Rethinking treasure (174-177) discusses this development in ninth- to eleventh-century Kashmiri Śaivism, with reference to the work of Ben Williams.

26 See Köppl, Establishing Appearances as Divine.

27 See Wangchuk, Defence of the Guhyagarbhatantra.

28 Dreyfus (Sound of Two Hands, 12-13, 128-131, 147-148) rightly corrects any such impression in his study of Tibetan scholastic practice, which focuses on the dGe lugs pa, but introduces comparison with the scholarly training and practice witnessed in the other schools. 


\section{Acknowledgements}

This work was supported by the DFG Germany under Grant number ME 2006/3-1, Nyang ral's Codification of rNying ma Literature and Ritual, at the Center for Religious Studies (Ceres) of the Ruhr-Universität Bochum.

Cathy Cantwell is an Associate Faculty Member at the Oriental Institute, University of Oxford, and an Honorary Research Fellow at the School of Anthropology and Conservation, University of Kent. She was a Mercator Fellow at the Center for Religious Studies (CERES) of the Ruhr-Universität Bochum (2018-2019). 


\section{References}

The TBRC reference numbers in square brackets refer to the electronic texts made available in the Tibetan text section of the Buddhist Digital Resource Center (BDRC), Cambridge, MA, USA (www.tbrc.org).

Cantwell, Cathy, The Action Phurpa ('phrin las phur pa) from the Eightfold Buddha Word, Embodying the Sugatas (bKa' brgyad bDe gshegs 'dus pa), revealed by Nyang-rel Nyima Özer (1124-1192, Tib. myang ral nyi ma 'od zer), BuddhistRoad Paper 7/2 (2020). Retrieved on 26 October 2020: omp.ub.rub.de/index.php/BuddhistRoad/catalog/book/156.

Cantwell, Cathy, Dudjom Rinpoche's Vajrakilaya Works: A Study in Authoring, Compiling and Editing Texts in the Tibetan Revelatory Tradition (Sheffield, 2020).

Cantwell, Cathy and Robert Mayer, Early Tibetan Documents on Phur pa from Dunhuang (Vienna, 2008).

Cantwell, Cathy and Robert Mayer, The Kilaya Nirvāna Tantra and the Vajra Wrath Tantra: Two Texts from the Ancient Tantra Collection (Vienna, 2007).

Cantwell, Cathy and Robert Mayer, A Noble Noose of Methods, the Lotus Garland Synopsis: A Mahàyoga Tantra and its Commentary (Vienna, 2012).

Doney, Lewis, The Zangs gling ma: The First Padamasambhava Biography. Two Exemplars of the Earliest Attested Recension (Andiast, Switzerland, 2014).

Dreyfus, Georges, The Sound of Two Hands Clapping: The Education of a Tibetan Buddhist Monk (Berkeley, 2003).

Dudjom Rinpoche, Jikdrel Yeshe Dorje, The Collected Writings and Revelations of H. H. bDud'joms Rin-po-che 'Jigs bral ye shes $r d o$ rje, bDud 'joms 'jigs bral ye shes rdo rje'i gsung 'bum, 25 vols. (Kalimpong 1979-1985 [TBRC W20869]).

Dudjom Rinpoche, Jikdrel Yeshe Dorje, The Nyingma School of Tibetan Buddhism: Its Fundamentals and History: The Translations, ed. and transl. from Tibetan Gyurme Dorje with the collaboration of Matthew Kapstein. Vol. 2: Reference Material, Gyurme Dorje and Matthew Kapstein (Boston, 1991).

Esler, Dylan, On the life of gNubs-chen Sangs-rgyas ye-shes, Revue d'Etudes Tibétaines 29 (2014) 5-27.

Esler, Dylan, The Lamp for the Eye of Contemplation, The bSam-gtan mig-sgron by gNubschen Sangs-rgyas ye-shes: Hermeneutical Study with English Translation and Critical Edition of a Tibetan Buddhist Text on Contemplation. Unpublished PhD thesis (Université catholique de Louvain, 2018).

Esler, Dylan, The Phurpa Root Tantra of Nyang-rel Nyima Özer's (1124-1192, Tib. Myang ral Nyi ma 'od zer) Eightfold Buddha Word, Embodying the Sugatas (Tib. bKa' brgyad bDe gshegs 'dus pa) Corpus: A Thematic Overview and Philological Analysis, BuddhistRoad Paper 7/1(2020). Retrieved on 26 October 2020: omp.ub.rub.de/index.php/BuddhistRoad/ catalog/book/155.

Grizman, Guy, Resurrecting an old advice: Funerary teachings in the Bka' brgyad cycle of Nyang ral nyi ma 'od zer (1124-1192), Revue d'Etudes Tibétaines 55 (2020) 182-197.

Gyatso, Janet, Apparitions of the Self, the Secret Autobiographies of a Tibetan Visionary (New Jersey, 1998).

Hirshberg, Daniel, Remembering the Lotus Born: Padmasambhava in the History of Tibet's Golden Age (Somerville, MA, 2016). 
Kapstein, Matthew, The Tibetan Assimilation of Buddhism: Conversion, Contestation and Memory (Oxford, 2000).

Kapstein, Matthew, The Tibetans (Malden, MA, 2006).

bKa' ma shin tu rgyas pa (snga 'gyur bka' ma) 120 vols. (Chengdu, 1999 [TBRC W25983]).

Köppl, Heidi, Establishing Appearances as Divine: Rongzom Chözang on Reasoning, Madhyamaka, and Purity (New York, 2008).

Mayer, Robert, »We swear our Grandparents were there!« (Or, what can the Sex Pistols tell us about Padmasambhava?) The making of myth in 10th-century Tibet and 2oth-century England, in: Olaf Czaja and Guntram Hazod (eds.), The Illuminating Mirror: Tibetan Studies in Honour of Per K. Sørensen (Wiesbaden, 2015) 341-355.

Mayer, Robert, Rethinking treasure: Part one, Revue d'Etudes Tibétaines 52 (Paris, 2019) 120-185. Myang ral nyi ma 'od zer, bka' brgyad bde gshegs 'dus pa'i chos skor, 13 vols. (reproduced from the complete mtshams-brag manuscript) (Paro, 1979-1980 [TBRC W22247]). Works specifically referred to: i. bka' brgyad bde gshegs 'dus pa'i gter ston myang sprul sku nyi ma 'od zer gyi rnam thar gsal ba'i me long, vol. 2 Kha, 199-381. ii. 'phrin las phur pa section, vol. 9 Ta, 343-503, and specifically, bka' brgyad bde gshegs 'dus pa las: byin brlabs phun sum tshogs pa phur pa'i bsgrub pa bi mā las mdzad pa zhi ba'i mchog [yon] tan spo ba'i cho ga, vol. 9 Ta, 351-365. = bKa' brgyad bde gshegs 'dus pa, 13 vols. (Gangtok, Sikkim, 1978 [TBRC W1KG12075]). Works specifically referred to: i. sprul sku mnga' bdag dag chen po'i skyes rabs rnams thar dri ma med pa'i bka' rgya can, vol. $1 \mathrm{Ka}, 1-164$. ii. 'phrin las phur pa section, byin rlabs phur pa'i sgrub pa, vol. 9 Ta, 55-221.

Snellgrove, David and Hugh Richardson, A Cultural History of Tibet (Bangkok, 2004).

Trautz, Nicholas, Curating a Treasure: The Bka'brgyad bde gshegs 'dus pa in the development of Rnying ma tradition, Revue d'Etudes Tibétaines 55 (Paris, 2020) 495-521.

Wangchuk, Dorji, An eleventh-century defence of the Guhyagarbhatantra, in: Helmut Eimer and David Germano (eds.), The Many Canons of Tibetan Buddhism (Leiden, 2004) 265-291.

Yeshe Tsogyal, The Lotus-Born: The Life Story of Padmasambhava, revealed Nyang Ral Nyima Öser, transl. from Tibetan Erik Pema Kunsang (Boston, 1993). 